\title{
EVIDENCE IN FEDERAL CRIMINAL TRIALS
}

\section{PENDLETON HOWARD $†$}

THE enactment of legislation empowering the Supreme Court of the United States to prescribe rules of pleading, practice and procedure in federal criminal trials represents the fulfilment of long cherished helief: of law reformers that judicial procedure in criminal (as well as in civil) cases should be formulated by the judges themselves. The subsequent appointment of an Advisory Committee to submit a draft of proposed rules seems to render desirable at this time a reconsideration of some of the vexed problems relating to the rules of evidence governing criminal proceedings in federal courts.

What are the sources of the present rules? In what respects have they been affected by existing legislation and by the course of judicial decision? How well have they worked in practice? Since the desire for uniformity was doubtless one of the principal motivating factors in the passage of the recent legislation, to what extent should the uniformity principle be translated into concrete form by the draft makers when they tackle problems relating to evidence? Would it be desirable, for example, to formulate a separate complete federal code of evidence? If not, would the formula enbodied in Rule 43 (a) of the Federal Rules of Civil Procedure be serviceable in criminal cases as well? Or is it still feasible to have conformity to state law with resulting diversities among judicial districts? These are practical problems difficult of solution. It is in the hope, however, that a reexamination of the more pertinent available material on the subject may at least point the way to tentative answers that the present paper has been written.

\section{I.}

An understanding of the historical development of the present federal evidence rules in criminal trials seems a necessary prerequisite to their evaluation. Irregular and sporadic development from principles of conformity with state practice to a broad policy of uniformity among federal districts has carried them through a maze of ambiguous and conflicting judicial and legislative pronouncements.

$\dagger$ Dean of the College of Law and Professor of Law, University of Idaho. Formerly Assistant District Attorney, New York County. Member of the New York, Tewas and Idaho Bars. Author of Crinimal Justice in Encland: A Study m Law AdanisTRATION (1931). 
The question whether state rules of evidence should be followed in trials in federal courts taxed the ingenuity of the founding fathers. The division of sovereignty between the state and the nation seemed to justify the adoption of a uniform body of evidence law applicable to all federal judicial districts. On the other hand, since there was no separate physical territory within which the jurisdiction of the newly created courts was exclusive, federal trials would necessarily be conducted by members of state bars familiar with local statutes and decisions and steeped in local tradition. Pragmatic considerations thus made desirable the adoption of the principle of conformity to state rules of evidence. This solution of the problem, at all events, was the one preferred by Congress in 1789. The Rules of Decision Act provided that "the laws of the several States, except where the Constitution, treaties, or statutes of the United States otherwise require or provide, shall be regarded as rules of decision in trials at common law, in Courts of the United States, in cases where they apply." 1 The conformity principle was continued and expanded in a series of subsequent enactments. ${ }^{2}$

But did the phrase "trials at common law," used in these Acts, include criminal prosecutions? In United States $v$. Reid, ${ }^{3}$ decided in 1851, this question was answered in the negative. The Supreme Court was here called upon to determine whether, in a trial in a federal court in Virginia for murder committed upon the high seas, a person jointly indicted with the accused, but separately tried, was competent to testify for the defense. Under a Virginia statute, adopted in 1849, such a witness was competent. This statute was held not to apply, however, on the ground that the requirement of conformity in "trials at common law" did not include criminal cases. The Court concluded that state legislation subsequent to 1789 should not govern the rules of evidence in federal criminal trials. The applicable rule was held to be the "law of the state, as it was when the courts of the United States were established by the Judiciary Act of 1789." The Court thought it obvious that "the only known rule upon the subject which can be supposed to have been in the minds of the men who framed these Acts of Congress, was that which was then in force in the respective States, and which they were accustomed to see in daily and familiar practice in the State Courts." 5 This view was confirmed, in the Court's judgment, by the provisions of Section 29 of the Judiciary Act of 1789 which "refers its courts and officers to the laws of the respective States for the quali-

1. Rev. Stat. $\$ 721$ (1878), 28 U. S. C. $\$ 725$ (1940).

2. Rev. Stat. $\$ 858$ (1878), 28 U. S. C. $\$ 631$ (1940); Rev. Stat. $\$ 862$ (1878), 28 U. S. C. $\S 637$ (1940); Rev. Stat. $\$ 914$ (1878).

3. 53 U. S. 361 (1851).

4. Id. at 363 .

5. Id. at 365 . 
fications of jurors and the mode of selecting them." The Court either disregarded or overlooked the fact that this section of the Act had been repealed in 1840 by a statute which imposed upon federal courts the state rules from time to time in force. ${ }^{T}$ The exclusion of the witness was approved on the ground that under the Virginia law of 1789 he was incompetent. As a consequence of the decision in the Reid case, therefore, federal criminal trials were left unaffected by principles of conformity with existing state law - a result characterized hy Wigmore as "singular and indefensible."

The Reid case left unsolved the problem of the law applicable to criminal proceedings in states admitted to the Union after 1789. In Logan v. United States, ${ }^{9}$ decided in 1892, the Supreme Court was asked to determine the competency of two witnesses, who had been convicted of felonies in state courts, to testify on behalf of the government. The case had been tried in a federal district court in Texas; one of the witnesses had been convicted of homicide in North Carolina and had served his sentence, the other had been convicted of two larcenies in Texas and subsequently pardoned. The Court held that the English common law in force at the time of the admission of Texas into the Union determined the competency of the witnesses. Following the doctrine of the Reid case, the Court said that the provisions of the Competency of Witnesses Act" to the effect that "the laws of the state in which the trial is held shall be the rules of decision as to the competency of witnesses in the Courts of the United States in trials at common law" had no application to criminal trials. Consequently a Texas statute enacted in 1858, making such witnesses incompetent, did not govern the matter. The Court fell back on a statute enacted by the Republic of Texas in 1836 making applicable to evidentiary questions "the common law of England, as now practiced and understood."11 Consideration of the principles of the common law led the Court to conclude that both witnesses were competent: the North Carolina convict because the disqualification did not apply beyond the limits of that state and the Texas convict because his incompetency had been removed by a pardon.

But in Benson $v$. United States, ${ }^{12}$ decided only some eight months after the Logan case, the Court began to shift its rationale. The case again presented the question of the competency to testify of a person jointly indicted with the defendant but whose separate trial had been

6. 53 U. S. 361 at 365,366 (1851).

7. Act of July $20,1840,5$ Stat. 394 .

S. 1 Wigarore, EVIDENCE (3d ed. 1940) $\$ 6(4)$.

9. 144 U. S. 263 (1892).

10. Rev. Stat. $\$ 858$ (1878), $2 S$ U. S. C. $\$ 631$ (1940).

11. 1 Republic of Texas Laws (1838) 156.

12. 146 U. S. 325 (1892). 
ordered. Here, however, the witness had been called by the prosecution instead of by the defense. It was urged that the point had already been virtually decided in the Reid case. The Court took the position, however, that that case was not decisive, since considerations of public policy which justified the exclusion of a defendant as a witness for his codefendant were not present in the case at bar. In speaking for the Court Mr. Justice Brewer said: "We do not feel ourselves, therefore, precluded by that case from examining this question in the light of general authority and sound reason." 13 Upon examination of the common law precedents, the Court pointed out that for fifty years the tendency had been to enlarge the domain of competency. This development, it was noted, had been wrought partially by legislation, both state and federal, and partially by judicial construction. The spirit of this legislation had controlled the decisions of courts and the technical barriers which had excluded witnesses from the stand had gradually been swept away. The Court, while recognizing some conflict in the authorities, concluded that the better common law view favored the competency, for the prosecution, of a co-indictee, although such testimony had been excluded in the Reid case when offered for the defense.

What was the scope and significance of the decision in the Benson case? Was it intended to alter the rule of the Reid and Logan cases that federal criminal courts must apply the law of the state as it existed in 1789 or at the time of the state's admission into the Union? In a careful discussion of the problem Professor Leach has answered this question in the negative. ${ }^{14}$ In all three cases, he points out, state statutes were ignored; in all three the weight of common law authority was examined and applied, either because it had been adopted by statute or because it was assumed that the law of the state at the time was in accordance with common law precedents. In the Reid case it was expressly held that the common law of the state where the trial was held

13. 146 U. S. 325,335 (1892) (Italics supplied). The trial was held in the Circuit Court of the United States for the district of Kansas. A Kansas territorial statute [KAN. Terr. Stat. (1855) c. 96, $\$ 1$ ] had adopted the common law of England. This statute was ignored in the opinion.

14. See State Law of Evidence in the Federal Conrts (1930) 43 Hanv. L. REv. 554, 559. In commenting further on this case the author writes: "The language of the Bcnson opinion mystified the lower federal courts for twenty-five years. Most of them continued to apply the Logan and Reid cases. And, indeed, in another case arising in Texas, the Supreme Court reaffirmed the Logan case without mention of Benson \%. United Statcs. Some of the lower courts, on the other hand, considered that the general common law was applicable, tempered by a policy toward the removal of the disqualification of witnesses. And some frankly did not know." Id. at 559-60. The case decided by the Supreme Court arising in Texas was Hendrix v. United States, 219 U. S. 79 (1911), holding that the wife of a defendant was not competent to testify in the federal courts on his behalf. 
at the time of its admission into the Union was applicable. While no similar declaration was made in the Benson case, in their decision in the Logan case, only eight months earlier, the same judges had reaffirmed the language of the Reid case. In the Benson case, Professor Leach argues, the Court was confronted with some conflict in the common law precedents and therefore felt it necessary to fortify its conclusion by reference to, and reliance upon, the trend of recent legislation and judicial decisions.

This argument is persuasive. A dozen years before it was made, however, the Supreme Court had taken a different view of things. In its decision in Rosen $\%$. United States, ${ }^{15}$ holding that a witness called by the government who had previously been convicted of forgery in a state court was competent to testify in a trial in a federal district court of New York, the Court maintained that the Reid decision had been "severely shaken" by the Logan and Benson cases. In stressing the dictum of the Benson case that such questions should be examined "in the light of general authority and of sound reason" the Court concluded that the "dead hand of the common-law rule of 1789" should cease to be controlling. ${ }^{16}$ Justices Van Devanter and McReynolds dissented from so much of the opinion as departed from the rule of the Reid and Logan cases, declaring that it was "in no way modified by what actually was decided in Benson $\%$. United States." 17

Insofar as it sanctioned progressive leadership by the courts of the nation in a field where leadership is sorely needed, the decision in the Rosen case is certainly defensible. As Dean Wigmore has pointed out, the effect of the decisions in the Reid and Logan cases was to cause the federal rules for criminal trials to be governed by "an artificial and unpractical test, which merely created needless obscurity and complication."18 For a century the outworn common law rules of incompetency had been undergoing a process of piecemeal statutory revision. Congress having failed to provide much-needed relief through legislation, the Court took things into its own hands. The unfortunate aspect of the opinion, however, lay in the fact that its language was too vague and cabalistic to constitute a helpful guide for the future. ${ }^{10}$ It was well enough to inveigh against the "dead hand of the common-law rule of 1789," but what was the significance of such phrases as "the trend of congressional opinion" and "the very great weight of judicial author-

15. 245 U. S. 467 (1918).

16. Id. at $470-72$.

17. Id. at 473 .

18. 1 WigMore. Evidence (3d ed. 1940) $\S 6(4)$.

19. In the lower federal courts there was much confusion. Two circuits hesitatingly recognized the authority of the Rosen case and four circuits adhered to the old rule. See WIGArore, op. cit. stpra note 18 , at $\$ 6(4)$, n. $15 ; \S 6 \mathrm{~b}$. 
ity"? Which of the many modern trends and innovations would receive judicial sanction in the future? Was the Court prepared to assume active leadership in the movement for reform or would it trim and compromise and continue to look to Congress for guidance?

Speaking for the Court only a year later, Mr. Justice Holmes used language which gave some hope: "It is argued that the Court was bound by the rules of evidence as they stood in 1789. That those rules would not be conclusive is sufficiently shown by Rosen v. United States . . ." But shortly afterward in Jin Fuey Moy v. United States, ${ }^{21}$ holding that a federal district court in Pennsylvania did not err in excluding the defendant's wife as a witness on his behalf, the Court reverted to the rationale of its earlier holdings. In speaking for the Court, Mr. Justice Pitney said:

"But a single point remains - hardly requiring mention - the refusal to permit defendant's wife to testify in his behalf. It is conceded that she was not a competent witness for all purposes, a wife's evidence not having been admissible at the time of the first Judiciary Act, and the relaxation of the rule in this regard by Sec. 858, Rev. Stats., being confined to civil actions. Logan v. Unitcd States . . . ; Hendrix v. United States. . . . But, it is saicl the general rule does not apply to exclude the wife's evidence in the present case because she was offered not 'in behalf of her husband,' that is, not to prove his innocence, but simply to contradict the testimony of particular witnesses for the government who had testified to certain matters as having transpired in her presence. The distinction is without substance. The rule that excludes a wife from testifying for her husband is based upon her interest in the event, and applies irrespective of the kind of testimony she might give." 22

Once again we have the Court harking back to the law in 1789 as a source of a rule of evidence, in the absence of congressional modification, and omitting all reference to the Rosen decision. Indeed, if the view announced in the Rosen case were still viewed with favor, it is difficult to understand the result in the Jin Fuey Moy decision. ${ }^{23}$

The confused state of affairs resulting from these contradictory lucubrations of the judicial mind was worse confounded by the opinion in Olmstead $v$. United States, ${ }^{24}$ decided eight years later. The Court held that evidence obtained by federal agents through the tapping of telephone

20. Greer v. United States, 245 U. S. 559, 561 (1918).

21. 254 U. S. 189 (1920).

22. Id. at 195.

23. The most reasonable explanation of the decision is that presented by Mr. Justice Sutherland in speaking for the Supreme Court in Funk v. United States, 290 U. S. $371,386-87$ (1933), to be discussed infra p. 771.

24. 277 U. S. 438 (1928). 
wires was not a search or seizure within the meaning of the Fourth Amendment and was admissible in a prosecution for violation of the National Prohibition Act. Noting the fact that this method of obtaining evidence was a misdemeanor under the IVashington law, the Court through Chief Justice Taft observed:

"While a Territory, the English common law prevailed in Hashington, and thus continued after her admissiun in 1889. The rules of evidence in criminal cases in courts of the United States sitting there consequently are those of the commun law. United Stales v. Reid . . . ; Logan 2'. United States. . . ; Rosen 2. United States. . . Withaup v. Unitcd States . . . Robinson v. United States. ...

"The common law rule is that the admissibility of evidence is nut affected by the illegality of the means by which it was obtained. . . .

"The common law rule must apply in the case at bar." "2J

Again, it would seem, the Court meant to go back to the rule of the Reid and Logan cases. But why the Chief Justice chose to cite the Rosen case for the proposition that the rules of evidence in federal criminal trials are governed by the law of the state where the trial occurs at the time of its admission into the Union is a mystery. Of the two other cases cited, Withaup a. United States ${ }^{20}$ held that the state law at the time of admission to the Lnion governs, while Robinson a'. United States $^{2 \pi}$ rejected such a test on the ground that "much that was said" in the opinion in United Statcs a'. Reid "has been weakened by the later decision of Rosen $v$. United Stutes." 28 The net effect of the Jin Fucy Moy and Olmstead decisions was to add enormuusly to the general confusion and uncertainty among the lower federal cuurts in their efforts to determine what rules of evidence should govern in criminal prusecutions. $^{29}$

In Funk a. United States, ${ }^{3 n}$ however, the Supreme Cinurt contributed a substantial doctrinal clarification. In holding that the wife of a defendant in a criminal trial in a federal court is a competent witness in his behalf the Court reverted unequivocally to the reasoning of the Benson and Rosen cases, repudiated the principles of the Reid and Layım

25. 277 U. S. $438,466-68$ (1928).

26. 127 Fed. 530 (C. C. A. Sth, 1903).

27. 292 Fed. 683 (C. C. A. 9 th, 1923).

28. Id. at 687 .

29. See 1 Wiguore, Evidence (3d ed. 1940) $\$$ ia (pt. II: Criminal Cares) and cases there cited; Leach, State Law of Eaidenti in the Fodcral Courts (1930) 43 Hans. L. REv. 554, 565-66.

30. 290 U. S. 371 (1933), (1934) 43 YALE L. J. 849 , (1934) It E. L. L. REs. 175, (1934) 22 Calif. L. Rev. 448, (1934) 19 CoRs. L. Q. 490 , (1934) 47 Hars. L. Rev. 853, (1934) 28 ILL. L. Rer. S46, (1934) 19 Iow L. Rev. 48S, (1934) \&2 U. of PA. L. Ra: 406. 
cases and expressly overruled Hendrix $v$. Unitcd Statcs ${ }^{\mathrm{at}}$ and Jin Fucy Moy $\approx$. United States. The importance of the opinion justifies stubstantial quotation. After reviewing the Reid and Logan cases and noting their influence on subsequent holdings, Mr. Justice Sutherland, spealing for the Court, said:

"Taking the two cases together, it is plain enough that the ultimate cloctrine announced is that in the taking of testimony in criminal cases, the federal courts are bound by the rules of the common law as they existed at a clefinitely specified time in the respective states, unless Congress has otherwise provided.

"With the conclusion that the controlling rule is that of the common law, the Benson case and the Rosen case clo not conflict; but both cases reject the notion, which the two earlier ones seem to accept, that the courts, in the face of greatly changed conditions, are still chained to the ancient formulae and are powerless to declatre and enforce modifications deemed to have been wrought in the common law itself by force of these changed conditions. . . .

"In both cases the court necessarily proceeded upon the theory that the resultant modification which these important considerations had wrought in the rules of the old common law was within the power of the courts to declare and make operativc." ${ }^{32}$

The Court concluded that the case at bar fell within the principles of the Benson and Rosen cases. The opinion noted the fact that the rules of the common law which disqualified as witnesses persons having an interest had long since in the main been abolished both in England and the United States. What was once regarded as a sufficient ground for the exclusion of such testimony had come to be uniformly considered as affecting merely its credibility. The Court pointed out that the modern rule which has removed the disqualification from persons accused of crime came into force gradually after the middle of the last century and is today universally accepted. ${ }^{33}$

Meeting squarely the argument that the Court should continue to enforce the old common law rule, no matter how contrary to modern thought and experience and how opposed to the trend of legislation and to the weight of judicial opinion it might be, merely because Congress had failed to legislate on the matter, the opinion declared that the duty of the Court was to decide the question "in accordance with present-day standards of wisdom and justice rather than in accordance with some outworn and antiquated rule of the past." ${ }^{34}$ Continuing, the Court said:

31. 219 U. S. 79 (1911). See note 14 sttpra.

32. 290 U. S. $371,379-80$ (1933).

33. The opinion stresses the fact that rules of evidence in their development "yield to the experience" of succeeding generations. $I d$. at 380-81.

34. Id. at 382 . 
"The final question to which we are thus bruught is not that of the power of the federal courts to amend or repeal any given rule or principle of the common law, for they neither lave nor claim that power, but it is the question of the power of these courts, in the complete absence of congressional legislation un the subject, to declare and effectuate, upon common-law principles, what is the present rule upon a given subject in the light of fundamentally altered conditions, without regard to what has previously licen declared and practiced. It has been said so often as to have inecome axiomatic that the common law is not immutable but flexille, anul by its own principles adapts itself to varying conditions. . . .

In overruling Jin Fucy Moy i. Inited States the Court pointed unt that in that case defense counsel had conceded that the wife was not a competent witness for all purposes, but contended that her testimuny was admissible in that instance because she was offered not to prove her husband's innocence but merely to contradict the evidence of government witnesses who had testified to certain matters as having transpired in her presence. This distinction had properly been held by the Court to be without substance. It was apparent, said Mr. Justice Sutherland, that in the Jin Fuey Moy' case the point most in the mind of the Court was the distinction relied upon, and not the basic rule which was not contested. In other words, the question had not heen properly presented and was disposed of - to recall MIr. Justice Pitney's language - as one "hardly requiring mention." 36

Shortly afterward, during the same term in which the Funk case was decided, the Supreme Court found an opportunity to amplify its recent pronouncement that modern standards of justice rather than obsolete rules of the past should govern the admission of evidence in federal criminal trials. In $W^{\prime}$ olflc $\boldsymbol{a}^{2}$. United States ${ }^{37}$ it reviewed a ruling of a federal district court in Washington admitting in evidence against the defendant in a criminal trial a statement contained in a letter from him to his wife, but proved by the testiniony of a stenographer, reading from her notes, to whom the accused had dictated the letter. The ruling had been upheld and the conviction sustained by the Circuit Court of Appeals, ${ }^{38}$ which had adopted as the test of admissibility its interpretation of the statute in force in the territory of Washington at the time of its admission to statehood. In sustaining the conviction the Supreme Court expressly rejected the reasoning of the Circuit Court of Appeals and said that the rules governing the competency of witnesses in federal criminal trials "are not necessarily restricted to those local rules in force

35. Id. at 383 .

36. Id. at 387. McReynolds and Butler, JI., dissented.

37. 291 U. S. 7 (1934).

38. Wolfle v. United States, 64 F. (2d) 560 (C. C. A. 9th, 1933). 
at the time of the admission into the Union of the particular state where the trial takes place, but are governed by common law principles as interpreted and applied by the federal courts in the light of reason and experience," citing Funk v. United States. ${ }^{30}$ The Court further declared that if any different rule with respect to the admissibility of testimony had been thought to apply in federal courts, it was clear that it should be the same as that governing the competency of witnesses. In other words, the decision on the point raised, in the absence of pertinent Congressional legislation, would be controlled by common law principles, not by local statute. The Court pointed out that the statement to which the witness was permitted to testify was a relevant admission evidencing criminal intent and hence rightly received in evidence unless it should have been excluded as a confidential communication by the husband to his wife. In rejecting the claim of privilegc, the Court through Mr. Justice Stone said:

“. . . Normally husband and wife may conveniently communicate without stenographic aid, and the privilege of holding their confidences immune from proof in court may be reasonably enjoyed and preserved without embracing within it the testimony of third persons to whom such communications have been voluntarily revealed. . . The privilege suppresses relevant testimony, and should be allowed only when it is plain that marital confidence cannot otherwise reasonably be preserved. Nothing in this case suggests any such necessity." 40

The Funk and Wolfle decisions seem to express the considered judgment of the Court and to lay down a fixed policy for the future. ${ }^{41}$ As regards both the competency of witnesses and the admissibility of testimony, federal rules of evidence in criminal trials will, in the absence of Congressional enactment, be governed by common law principles as interpreted by the federal courts "in the light of reason and experience." They will not be controlled by local statute. While the rules of evidence will be decided according to the principles of the common law, in determining what rule shall govern, the Court will feel free to take cognizance of altered conditions, the course of legislative change and the weight of current judicial authority. The common law to which the Court will look, therefore, is not the common law of the states in 1789 or at the date of their admission into the Union or with reference to any other fixed period of time, but a common law modernized and adjusted to meet the tested needs of experience. To put the matter plainly, what the Court has said is that the law of evidence in federal criminal trials

39. 291 U. S. 7, 12 (1934).

40. Id. at 16-17.

41. See, e.g., the subsequent reference to the Funk case in United States v. Wood, 299 U. S. 123, 144 (1936). 
today is whatever the judges, in their collective wisdom but with due regard to modern trends, shall from time to time decide it to be.

Aside from the commendable achievement of the Court in escaping finally from the bondage of antiquated rules no longer suited to current needs, the chief significance of the two decisions lies in the triumph of the uniformity principle. The clash between the apposing ideals of uniformity and conformity which gave us Saift a. Tyson ${ }^{42}$ and Fric Ruilroad Company ${ }^{\prime}$. Tompkins ${ }^{23}$ in the domain of substantive law has heen resolved in favor of the former in the development of evidentiary rules for federal criminal trials. The last vestige of the "static conformity" doctrine" of the earlier decisions has been swept away. And yet it may well be asked whether substantial uniformity can be expected in future decisions of the lower federal courts. Much of the confusion heretofore existing in these courts has, it is true, been due to inconsistent ant uncertain pronouncements of the Supreme Court. While that tribunal seems finally to have recognized its responsibilities and promises more vigorous leadership in the future, it must be recalled that many important cases never go higher than the circuit courts of appeals. With often no standard except "reason and experience" to guide them, these courts will doubtless continue to reach varying conclusions as to what constitutes the better modern view on any specific evidentiary prollem. The result will be conflict and uncertainty until the issue is finally settled by the Supreme Court, which may be a matter of years. The process of judicial selection, clarification, delimitation and correction is at best a slow one. Moreover, past experience demonstrates the importance of stare decisis in this branch of the law. Courts have usually been reluctant to disregard precedent in meeting new situations. Perhaps, therefore, it would be more accurate to say that the uniformity principle has triumphed as a result of the Funk and Irolfle decisions only insofar as that principle can triumph in the absence of more extended codification. The path has at least been cleared for a progressive develijgment of evidence law in federal criminal trials.

\section{II.}

The desirability of both speed and certainty in the administration of criminal justice has repeatedly been enphasized by legal reformers and commentators. The funds of litigants are unnecessarily wasted by timeconsuming appeals in which parties find it advantageous to urge that the trial courts erred in the admission or rejection of testimony. The dockets of appellate courts should not be cluttered with cases which do nut justify

42. 16 Pet. 1 (U. S. 1842).

43. 304 U. S. 64 (1938). 
appellate consideration on their merits. As we have seen, moreover, in seeking to prevent undesirable results these courts have too often only added to the general confusion. We come back, therefore, to the question posed at the beginning of this paper: what provision, if any, should be made in the Rules of Criminal Procedure in respect to the law of evidence governing criminal trials in federal courts? Two proposals for reform have struggled for supremacy in the legal literature of this subject: (1) conformity to state law with some diversities among judicial districts, and (2) the formulation and adoption of a separate complete federal code of evidence for use in both criminal and civil cases. Let us consider each of these suggestions in the light of the existing situation.

One of the leading arguments advanced in support of the first of these proposals is based upon the existence of state bars familiar with local statutes and state judicial decisions and well versed in local customs. It is said that the learning of these practitioners should be utilized and their convenience considered in the formulation of rules of evidence in federal trials. It is pointed out that most of the progress achieved in the development of the law of evidence to meet modern conditions has come through forward-looking state legislation and the decisions of state courts. A body of appellate court decisions interpreting local statutes is already in existence and could be utilized in the federal prac* tice. Against uniformity it may also be urged that two procedtural systems create instances in which divergent results are obtainable in the same state. Under such reasoning the decisions in the Reid and Logan cases that federal criminal prosecutions are unaffected by the several acts of Congress requiring conformity to state law should be repudiated. Professor Leach, an advocate of the conformity solution, stums up the matter thus :

“. . . In diversity of citizenship cases, conformity would seem clearly desirable. In the exclusive jurisdiction, it seems the best way out of a difficult situation. The states have shown a laudable tendency to advance, and the progress on the whole is generally conceded to have been wise. State legislatures contain a large number of members of the bar whose professional activities have been interrupted, if at all, only temporarily in the interests of politics. They keep a close eye on the administration of the courts, and have a reasonably sound understanding of their problems. The diversities between states, moreover, are not extensive. Some states have been recognized leaders in the advance, but well-considered and successful reforms have percolated throughout the Union without unreasonable delay. The most marked example of this is the reform toward removal of common law clisqualifications of witnesses with which the federal courts in criminal cases have had the most difficulty. The boon to the state bar of a fecleral law of evi- 
dence conforming to state practice cannot, of course, he overemphasized." 44

Answering the argument that conformity to state legislative and judicial reforms in the law of evidence would put too great a burden of work on federal judges who sit in several jurisdictions and must hence familiarize themselves with divergent systems of state law, the author points out that the hardship on the judge is no greater than the hardship placed on the bar by absence of conformity, and probably less since cuunsel have the duty of instructing the court on matters pertaining to local law. ${ }^{45}$ Professor Leach is not impressed, moreover, with the suggestions that it would be below the dignity of the United States to subject its courts in matters of evidence to regulation by state law, and that state statutes conceivably might obstruct federal criminal law enforcemunt. Congress has already required its courts to apply state law in many ficlds and that body surely has ample constitutional authority to prevent any attempted frustration of the administration of federal criminal justice. ${ }^{\text {in }}$

Conceding the merit of many of the points advanced in favor of conformity, the solution seems no longer tenable. The Supreme Court in 1933 in the Funk and $W$ olfle cases has taken its stand in support of the uniformity principle. It is extremely unlikely that it will now reverse its position and countenance general conformity to state law in evidentiary matters in its forthcoming Rules of Criminal Procedure."7 Furthermore, it is of significance that in the Rules of Civil Pracedure for the District Courts of the United States, adopted by the Supreme Court in 1937 pursuant to the Act of $1934,{ }^{48}$ the practice followed since 1872 of conformity in law actions to the procedure obtaining in the

44. Leach, State Law of Ezidince in the Federal Courts $(1030)$ 43 H.Mns. L. REv. 554, 583-\$4. For another argument in support of confurmity see Nute (1434) 43 Y.uL L. J. 849. The subject is also discussed in Callahan and Ferguson, Eridente and the New Federal Rules of Civil Procidure (1930) 45 Y.uLE L. J. 622. 1044-47; Sweeney, Federal or State Rnles of Evidente in Federal Courts (1932) 27 ILt. L. KEv. 344, 397-44.

45. Leach, supra note 44, at 584 . The effect of the decision in Fric Roilrad io. a. Tompkins has been to cast an added burden on federal judges to familiarize themselves with state substantive law.

46. Ibid.

47. Mr. Leach's article, it should be noted, was written a dozen years ago and befure the decisions in these cases. Moreover, Leach himself cuncedes that "if Congress wuth provide a code of evidence and keep it modernized, a Ctopian ideal would he realized." See Ieach, supra note 4 , at $\$ 83$.

48. 48 Stat. 1064 (1934), 28 U.S.C. $\$ 723$ (b)\&(c) (1940). V'igmire notes that the desirability of this change was urged by the great majority of those interested in federal procedure. He says further: "Those who urged this legislation relegating the whule subject to the rule-making power of the Supreme Ciurt were agreed that a general change from the mutilated conformity policy would eventually be advisable. Fither the Federal rules of Evidence should be developed unifurmly thrughhout the circuits and independently of State rules, or else be made to confurm strictly to the current State 
particular state was abandoned in favor of distinctive federal rules. Independence and uniformity were substituted for partial conformity to local procedural law. It is true, of course, that the epochal decision in Erie Railroad Company \%. Tompkins, ${ }^{40}$ overruling Srvift $v$. Tyson, substituted complete conformity to local stubstantive law for partial independence. Save in matters governed by the Federal Constitution or by Acts of Congress, the law to be applied in any case is the law of the state. And it is not a matter of federal concern whether the law of the state is declared by its legislature in a statute or by one of its courts in a decision. It is also of interest that Mr. Justice Brandeis, who was alone among the justices in declining to approve the new rules of independent procedure, uniform for all the fecleral courts, wrote the opinion in this milepost case which "abandoned the icleal of a uniform nationwide common law of the states and recognizes the complete autonomy of forty-eight systems of judge-made substantive law." "Th "The seeming anomaly that at the same term of court the Supreme Court should have adopted uniform rules of procedure while announcing a doctrine of diversity in substantive law has evoked much interest and discussion. ${ }^{52}$ But however indistinct and illusory in practice the dividing line between substance and procedure, it is well recognized that in the latter sphere the federal courts act inclependently, except where federal statutes or rules of court may prescribe conformity, partial or complete. ${ }^{\text {st }}$

It is appropriate at this time to advert to the fornula embodied in Rule 43(a) of the Federal Rules of Civil Procedure. Members of the Advisory Committee which drafted these rules, we are told, were reluctant to deal with the thorny problem of evidence. ${ }^{54}$ Whether this was due to lurking doubts as to the Supreme Court's power to control

practice (subject only to exceptions expressly formulated for Federal practice). In either event, the Federal Supreme Court, and not Congress, was best qualified to bring about exact conformity or to direct the detailed changes. Considerable merit was clained for each alternative,-complete uniformity or strict conformity." 1 WIGNORE, EUIDENC: (3d ed. 1940) $\S 6 \mathrm{~b}$.

49. 304 U. S. 64 (1938).

50. 16 Pet. 1 (U. S. 1842).

51. N'McCormick \& Hewins, The Collapse of "General" Law in the Federal Courts (1938) 33 Int. L. Rev. 126. This article contains an excellent discussion of the historical background and implications of the decision.

52. See, e.g., Holtzoff, The Federal Rulcs of Civil Procedure and Eric Railroud Co. v. Tompkins (1940) 24 J. Am. Jud. Soc. 57; Clark, The Tomplins Casc and the Federal Rules (1941) 24 J. Ax. Jun, Soc. 158.

53. McCormick \& Hewins, supra note 51 , at 142.

54. See Proceedings of the Cleveland Institute on Feneral Rules (1938) 186; Proceenings of the Atlanta Institute on Federal Rules (1938) 72; Mitchell, Allitude of Advisory Committec-Events Leading to Proposal for Uniform Rules-Pralilems on Which Discussion Is Invited (1936) 22 A. B. A. J. 780, 782. 
the subject-matter, ${ }^{55}$ or to the inherent difficulties involved, or to a disinclination to precipitate objections in Congress from lawyers who might take exception to particular provisions and hence delay adoption of the rules, or - what is more likely - to a combination of all these factors, need not now concern us. But apparently the Court's decision to have the rules provide for unification of legal and equitable remedies in one form of action caused the Committee to conclude that some provision relating to evidence was essential. ${ }^{56}$ Rule 43 was the result. Subdivision (a) provides for a limited conformity in that the local state rules are to be followed in the trial court, unless a federal statute or court rule is applicable. The wording is novel and far from clear:

Form and Admissibility. In all trials the testimony of witnesses shall be taken orally in open court, unless otherwise provided by these rules. All evidence shall be admitted which is admissilje under the statutes of the United States, or under the rules of evidence heretofore applied in the courts of the United States on the hearing of suits in equity, or under the rules of evidence applied in the courts of general jurisdiction of the state in which the United States court is held. In any case, the statute or rule which favors the reception of the evidence governs and the evidence shall be presented according to the most convenient method prescribed in any of the statutes or rules to which reference is herein made. The competency of a witness to testify shall be determined in like manner.

The recent appearance of Professor Green's scholarly article discussing the meaning and operation of this rule renders unnecessary its extended consideration in this paper. ${ }^{57}$ His conclusion - well fortified by documentation - is that the rule has not supplied that certainty which before its adoption was thought to be the primary need of federal evidence. Nor, in his judgment, has it furnished the simplicity and liberality so

55. See Wickes, The New Rule-Making Pocier of the Eniled Slates Suprenc Court (1934) 13 TEx. L. Rev. 1; Sunderland, Character and Extent of the Rule-Wfaling Pouzr Granted U.S. Supreme Court and Ircthods of Effectiec Excrise (1935) 21 A. B. A. J. 404; Clark, Pouter of the Supreme Court to Make Rules of Appellate Proccdure (1936) 49 Harv. L. REv. 1303; Green, To IThat Extent Jay Courts Under the Rule-Maling Pouter Prescribe Rules of Eardente? (1940) 26 A. B. A. J. 482; Grinnell, To What Extent May Courts Under the Rule-lMaking Poator Prescribe Rules of Eatidence? (1940) 24 J. Axr. Jun. Soc. 41; Dean, Rule-Maling for Criminal Procedure (1940) 24 J. Ass. Jun. Soc. 81; Wigmore, Legislafure Has No Poaier in Procedural Field (1940) $24 \mathrm{~J}$. Aar. Jud. Soc. 70.

56. See Proceennas of Clemeland Institute on Feneral Rules (1938) 186; Pro-

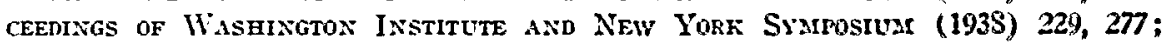
Mitchell, Attitude of Advisory Committec-Eicuts Leading to Proposal for Uniform Rules-Problems on Which Discussion Is Intifed (1936) 22 A. B. A. J. 780, 782.

57. The Admissibility of Evidence l'nder the Federal Rules (1941) 55 Hanv. L. REv. 197. 
sorely needed in evidentiary matters generally. Its provisions concerning federal statutes and state law do not aid materially in modernizing the rules, since many of the badly needed evidence reforms have not been adopted by Congress, by the federal courts nor by any large number of states. The evidence decisions of federal courts do not disclose greater liberality than those of the state courts. In the decisions of the lower federal courts especially he notes instances of extreme conservatism. He concludes as follows:

“. . The federal courts are following much the same doctrines as before. Adequate improvement can come only through legislittion, preferably by rules of court. There is some difference of opinion concerning the amount of detail which a set of formulated rtiles of evidence should contain. Perhaps the code now in preparittion by the American Law Institute will furnish a starting point, but this code will not be ready for several years. In the meantime Rule 43 must be endured, and a better understanding of its provisions is desirable. The fact that subdivision (a) is a malieshift, however, should not be forgotten, and when its purpose as a stopgap has been served and a satisfactory sulbstitute has been prepared, the :present rule should be discarded." 58

The unfavorable character of Professor Green's report affords no strprise to those who expected little relief from the nystifying ambiguity of this fumbling, if sincere, attempt to bring order out of chaos. We must look elsewhere for a solution.

The desirability of a federal code of evidence has frecuently been urged, although the suggestion has usually been coupled with the admission that it represents a Utopian ideal. ${ }^{\text {50 }}$ The opportunity now thought to be afforded, to incorporate such a codification in the Federal Rules of Court has stimulated further discussion of the possibilities inherent in the project. The claim is advanced that such a code could include recent meritorious legislative innovations and the more workable proposals for the modernization and simplification of evidence law, and could be revised and kept up to date by appropriate changes in the rtles. Divergent and outmoded judicial rulings could be corrected and the number of time-consuming appeals on contested evidence points curtailed. Codification would be advantageous for the lower federal judiciary since it is customary to assign district judges temporarily to judicial districts outside their home states, where their services may be needed to relieve congested dockets. The federal specialties of bankruptcy and

58. Id. at 225 .

59. See the discussion of this subject in Sweeney, Federal or State Rules of Extidence in Federal Courts (1932) 27 Ir.L. L. Rev. 394, 399; Callahau \& Ferguson, Evidence and the Neze Federal Rules of Civil Procedure (1936) 45 Y ALE L. J. 622, 644.47; Leach, State Law of Evidence in the Federal Courts (1930) 43 Hakv. L. Rev. 554, 583.84. 
patents could be uniformly and more satisfactorily administered through the adoption of a uniform method of proof. The Supreme Court would have the opportunity to assume effective leadership in a constructive movement for legal reform in a branch of the law where leadership is a pressing need. The case for uniformity was succinctly summarized a few years ago by Mr. Wigmore:

"The truth is that the time seems to have come, for the rules of evidence as for procedure in general, when the pristine principle of conformity must be abandoned in the practice of the Federal Courts. It is more important, under modern conditions, that Federal practice all over the Nation should be uniformly consistent with itself than that it should, by varying, conform chameleonlike to lacal State practice. A general re-casting of the Federal rules of evidence is therefore to be expected whenever the principle of Federal unifornity finds full acceptance in legislation and in rules of Court."

The fact that a distinguished group of experts in the law of evidence, under the favorable auspices of the American Law Institute, are now engaged in the Promethean task of formulating a model Code of Evidence has given rise to the suggestion that their labors might be utilized to good advantage in any attempt at federal codification. The group responsible for this model code have recently submitted a second tentative draft for the purpose of securing criticisms and suggestions for its improvement from all branches of the legal profession. ${ }^{01}$ How long it may take to complete this project is not known, but the finished product will probably not be available for some time. It has been suggested that it would be desirable for the Committee on the Rules of Civil Procedure and the Committee on the Rules of Criminal Procedure to meet with the Evidence advisory group in an endeavor to reach a common ground. This is a constructive suggestion and one, it is hoped, that will bear fruit.

The tremendous difficulties involved in drafting a model code that can be expected to receire the approval and active support of practitioners, judges and legal scholars are brought sharply into focus by the recent adverse comments on the work of the American Law Institute group by the most eminent writer and scholar of his generation in the law of evidence. As noted above, Mr. Wigmore fully recognizes the desirability of substituting the ideal of uniformity for that of conformity in the rules of evidence in federal trials. Nevertheless, writing in the January issue of the American Bar Association Journal ${ }^{62}$ he expresses vigorous opposition to the draft code finally formulated and offered to

60. Wigmore, Selected Cases on Evinexce (3d ed. 1932) 1020.

61. The American Law Ixstitute Cone of Evidence (Tent. Draft No. 2, 1941 ).

62. The Anerican Law Institute Code of Eridence Rules: A Dissent (1942) 23 A. B. A. J. 23. 
the Institute last May. He sets forth six postulates of method and style on which he thinks it is desirable for the draftsmen of a code to agree. The code submitted, in his judgment, "fails substantially to conform sufficiently to any one of these postulates." 63 His disagreement, he notes, is not so much with the policy of many of the code's rules as such (although he thinks some of the specific rules do not go far enough and others go too far) but rather with the draftsmanship. In conclusion he says:

"Reviewing this cumulation of shortcomings, on the whole might not a cold-hearted critic describe this Draft Code somewhat as follows: "This is an academic composition, meritorious as a record of aspirations, and highly significant as a symptom that Bench and Bar are ready for considerable progress; but not meriting legislative favor, first because its advanced proposals are far too radical at the present time, and secondly because its imperfections in the formulation of the rules render it quite unfit for practical use." "04

Wigmore, as he himself notes, in the past has been taxed with being "too radical, too advanced." The fact that he views many of the specific proposals in this draft code - aside from any questions of draftsmain" ship - as too advanced for the bench and bar at the present time is disquieting. It affords some indication of the lack of warmth with which the rank and file of the legal profession may be expected to view its innovations. The Reporter doubtless will be able to defend himself and his advisers against Mr. Wigmore's strictures, although some of them seem by no means easy to answer. But these sharp differences of opinion among distinguished experts and commentators illustrate forcibly the great practical difficulties of code-making. If the legal scholars are unable finally to agree among themselves, what likelihood is there that they can sell their wares to the practitioners, judges and public officials who comprise the bulk of the legal profession?

Despite these difficulties, however, the situation is far from being hopeless. Within recent years practicing lawyers have lost much of their attitude of extreme conservatism toward reformation of the rules of evidence. The researches and writings of pioneer scholars, the opinions of progressive courts, the hostility of laymen - all these factors have influenced their thinking. The time is probably not far distant when a rational and simplified code of evidence will be embodied in court rtules. As Dean McCormick has aptly observed in a challenging article:

"In the other fields of procedure we have come to see that the road of progress is the way of comparative study. By examining the results of experiments in other states and countries, and by selecting the devices that have proven successful in practice, a body

63. Ibid. (Italics are Wigmore's).

64. Id. at 28 . 
of knowledge of scientific code-making has been developed, with notable recent results. Comparative research and an openminded willingness to profit by the experience of others, are the path of improvement in evidence law."

As already indicated, there would seen to be no reason why the three groups now directly concerned with reshaping the law of evidence in the federal courts should not meet in an earnest effort to reach a solution of their problems. ${ }^{66}$ The task of composing inevitable clashes of opinion calls for the exercise of judicial statesmanship of a high order. The American Law Institute Code is a tentative draft. In order to insure a favorable reception of its provisions, its framers would doubtless be willing to alter it materially in the light of criticisms and suggestions from responsible and informed sources. The acceptance or rejection of any specific proposal should depend, in the final analysis, upon considerations of expediency as well as of intrinsic merit. Wignore's forcible objections to the code on the score of its draftsmanship should be carefully and objectively weighed. Reforms and innovations that are deemed to be too extreme or doctrinaire may have to wait until a later day.

The formulation of a code that will at once free the rules of evidence from archaic and restrictive encumbrances, satisfy the tested needs of experience and command the substantial support of the bench and bar is an achievement that may well be the work of years. Meanwhile it is probably desirable to incorporate in the Federal Rules of Court some evidence provisions of a less thoroughgoing and definitive character. Here Wigmore's suggestion seems to offer the most workable and satisfactory immediate solution. He proposes that certain specific evidentiary rules now thought to be desirable by the Supreme Court be formulated, that the remaining scattered federal statutes be left as they are, and that all other disputed matters, for the time being, he relegated to state practice for conformity. His suggested rule, offered as a substitute for Rule 43(a) of the Rules of Civil Procedure, specifies that in trials before a jury the rules applicable to the consideration of evidence shall conform to state law and practice, except as otherwise provided either by the Constitution, laws or treaties of the United States, or by the Rules of Court. $^{67}$ The remaining provisions of Rule 43 would be left intact.

65. Tomorrow's Law of Evidcnce (1938) 24 A. B. A. J. 507, 581.

66. The Supreme Court has a continuing Advisory Committee on Rules of Civil Procedure which is requested to prepare and submit to the Court such amendments as they may deem advisable to the Rules already adopted. See the court order and committee report, 1 F. R. D. 79 (1940).

67. See 1 Wignore, Evidence (3d ed. 1940) $\$ 6 d$ for further explanation of this suggestion. It should be noted that in addition to Rule 43 , other rules deal with evidence matters. See Rules $26-37,44,45,46,50,61,68,80$. 
The opportunity would thus be presented to the Court in the immediate future, through its advisory groups, to introduce a greater degrece of uniformity into the federal law of evidence by formulating rules relating to some of the more fundamental and less controversial matters, leaving disputed points for further consideration and decision. In this connection, if it were thought desirable for any reason to include in the Rules of Criminal Procedure any special evidentiary provisions relative to the trial of criminal cases, this could be readily accomplished. The result would be a limited amount of codification through Rules of Court. It would, of course, be something in the nature of a stop-gap until such time as a complete and definitive federal code of evidence could be agreed upon. 